\title{
DETERMINANT FEXECUTORS OF THE EFFECTIVENESS OF TOURISM DEVELOPMENT POTENTIALS AND ITS DEVELOPMENT MODEL IN SAROLANGUN REGENCY, JAMBI, INDONESIA
}

\author{
Novita Wulandari \\ Doctoral Program of Government Science, Satyagama University, Jakarta, Indonesia \\ Email :wulanrhendhu@gmail.com
}

\begin{abstract}
This study aims to analyze the Effect of Policy Implementation, Investment, and Business Executors on the Effectiveness of Tourism Potential Development in Sarolangun Regency, Jambi Province. This research uses a quantitative approach with explanatory research type, with a population of 74,660 people and a sample of 100 people determined by the Slovin formula. Data collection techniques in this study were using documentation, observation, questionnaire, and literature techniques. The results of the study prove that Policy Implementation has an effect of $51.3 \%$, Investment has an effect of $15.5 \%$, Business executors have an effect of $52.6 \%$, Policy Implementation, Investment and Entrepreneurs together have a $52.8 \%$ effect on the Effectiveness of Tourism Development. Recommendations from the results of this study are that the implementation of the policy must be supported by a law on tourism and RIPPARDA. Thus, mapping the tourism area which is supported by multistakeholder policies and cooperation, will open up large investment opportunities in the tourism sector. Organizational restructuring of the regional tourism office as a business executor from a structural dimension. These three variables must get attention, so they can form quality human resources for the benefit of tourism development in Sarolangun Regency.
\end{abstract}

Keywords: Policy Implementation, Investment, Business Executors, Effectiveness and Tourism

\section{Introduction}

Tourism is one of the main sectors to boost the economy of the people in Indonesia. Sarolangun as one of the regencies located in Jambi Province, has diverse tourism potentials to be developed, namely: Nature Tourism, Cultural Tourism, Sports Tourism, Special Interest Tourism, Artificial Tourism, Historical Tourism, and Culinary Tourism. The tourism potential in Sarolangun Regency must be developed, supported by innovative development and development of the tourism area. According to Swarbrooke, tourism development is a series of efforts to realize integration in the use of various tourism resources and to integrate all forms of aspects outside tourism that are related either directly or indirectly for the sustainability of tourism development (Tsuraya and Slamet, 2018).

Tourism that can be developed in Sarolangun Regency is Educational Tourism, because the majority of tourism in Sarolangun Regency is inseparable from the legend or history and culture in Sarolangun Regency. Educational tourism or Edu-tourism is a program where tourists visit a tourist location with the main purpose of gaining a direct learning experience at the tourist 
attraction (Rodger, 1998: 28). Whereas the Directorate General of PHKA defines Edu-tourism as a diversification of tourist attractions from natural tourism (ecotourism) which aims to expand and reproduce natural tourism products (DG PHKA, 2001). Until educational tourism or Edutourism can be interpreted as a sub type of nature or ecotourism tourism. a model that can be developed based on the community, namely by providing opportunities for the community to participate in tourism management. The Haburas Foundation has realized a community-based tourism program aimed at increasing the source of community income without creating dependency on just one business, equitable distribution of community income, community empowerment, preservation of local culture, and supporting environmentally sound development (De Carvalho et al, 2008).

The Sarolangun Regency Government must be able to make innovative and sustainable regional tourism development and development plans. This can be realized through the implementation of policies that can be seen from the Regional Regulation (PERDA) / Regent Regulation (PERBUP) regarding Sarolangun District Tourism, and the Regional Tourism Development Plan (RIPPARDA). Other forms of innovation in synergizing business executors / tourism stakeholders need to conduct socialization and community empowerment and improve the quality of human resources, especially communities around the destination, so that they have the initial capital of knowledge in serving tourists, so that regions are ready to compete both regionally and nationally. In addition, the provision of sanitation, parking, places of worship, restaurants / restaurants, lodging and souvenir shops around the tour will be able to increase the feasibility of tourist destinations.

According to Chief J.O. Udoji in Solichin (2008: 5), public policy is "an sanctioned course of action Addressed to a particular problem or group of related problems that affects society at large". Gordon, stated that implementation is related to various activities directed at the realization of the program (Keban, 2008: 76). Thus the implementation of policies according to Dunn (1999: 80) is defined as the implementation and control of the direction of action until the achievement of policy results or a process of achieving the goals set. Dunn (1999) classifies several variables that are measured through the process: (a) problem formulation, (b) forecasting, (c) recommendations, (d) monitoring, and(e) evaluation. The implementation of policies is also a supporter of regional investment, with policies being implemented in the form of laws (Laws), Government Regulations (PP), Presidential Regulations (Perpres), or Perda (Pergub / Perbup / Perwal). Tourism Investment Policy, will be able to open up opportunities for investors while guaranteeing investors that the funds invested in the area are safe.

Deliarnov (1995: 123) states that investment is the company's overall expenditure which includes expenses to buy raw materials or materials, machinery, and fexecutory equipment, as well as all other capital needed in the production process, expenses for office building, building premises residences of employees and other construction buildings, as well as changes in the value of stocks or reserves as a result of changes in quantity and price. This variable is measured through dimensions: (a) innovation, (b) technology, (c) level of economy, (d) level of profit, and (e) political situation. Investment is expected to expand its role within the framework of national development policy in general, and regional development in particular. Some basic considerations include: (a) macroeconomic stability; (b) balance between regions; (c) balance between sectors; and (d) the balance between social groups while completing the role of domestic projects and meeting the requirements for their implementation. 
In addition to policy and investment The development of tourism is inseparable from the role of stakeholders, to play an active role in the development of tourism objects, including marine tourism, namely the government, private sector, and the community (Rahim, 2012: 1). This is because business executors are considered to be very helpful in improving the economy in the regions. Business executors arise in line with the development of society, and the increasing needs of the community both in the goods or services sector. Regional development, economic growth, investment, development of tourism potential, all government activities are inseparable from the participation of businesses. The existence of businesses, the economic cycle of the region and the center can run, of course, supported by government policies in the form of local regulations. Stakeholders according to Hetifah (2003: 3) are interpreted as individuals, groups or organizations that have interests, are involved, or are affected (positive or negative) by development activities or programs. Freeman (2004) states that business executors are a very important group for the survival and success of a corporation. This variable is measured through dimensions: main stakeholders and supporting stakeholders.

Tourism development essentially involves three interrelated stakeholders, namely the government, private sector, and the community (Rahim, 2012: 1). Each stakeholder has a different role and function. This needs to be understood, so that the development of tourism in an area can be realized and implemented well. Tourism development needs to be done to improve or advance the tourism sector both at the state and regional levels. According to Sunaryo (2013: 129), tourism development is a process of basic changes made by people in a planned manner in a certain tourism condition which is considered unfavorable, directed towards a certain tourism condition that is considered better or desirable.

On that basis, a study was conducted in Sarolangun Regency with the title: "Implementation of Policies, Investment and Business Executors in the Effectiveness of Developing Tourism Potential in Sarolangun District", where the research objectives are: (1) Analyzing the magnitude of the effect of Policy Implementation on the Effectiveness of Tourism Potential Development in Sarolangun Regency. (2) Analyzing the magnitude of the effect of Investment on the Effectiveness of the Development of Tourism Potential in Sarolangun Regency. (3) Analyzing the magnitude of the influence of business executors on the Effectiveness of the Development of Tourism Potential in Sarolangun Regency. and (4) Analyzing the magnitude of the effect of simultaneously implementing policies, investments and business executors on the effectiveness of tourism potential development in Sarolangun regency.

Benefits This research is expected to provide the best input for the people of Sarolangun Regency, especially in priority locations for tourism destinations in an effort to develop Tourism as a source of increased income, as well as providing input for the Government and Local Governments in formulating policies involving stakeholders to increase regional investment from the sector tourism.

\section{Research Methods}

The method used to examine the research questions was by using a quantitative and qualitative methods. The quantitative data was collected by using questionnaires distributed to 100 sample respondents. This sample was chosen by simple random sampling method. Whilst the qualitative method was taken by undertaking field observation, interviews, and Focus Group Discussion (FGD) with the relevant stakeholders. The interview was conducted by interviewing 
the key persons, namely, the Head of the Youth and Sports office (Dispora), Historians and Communities around tourist sites. These primary data were collected in two sub-districts, namely, Sarolangun and Limun sub-districts, Sarolangun Regency, the province of Jambi. In addition to the above primary data, secondary data and literature review and web search were also undertaken. Note that, the statistical method used is multiple regression analysis with the Statistical Package for the Social Science (SPSS) as software to estimate the model.

The qualitative method used to formulate tourism development model was by conducting Focus Group Discussion (FGD) at the hall of the Sarolangun Regent's office. Participants who participated in the Focus Group Discussion or workshop include the staff of tourism office in Sarolangun regency, Representative of the Indonesian National Police, Representatives of sub regency of Sarolangun Regency, Lecturers, Universities' students, as well as high school students and Media Representatives. Method to collect the data and information were by applying the SPWT (Integrated Regional Development Scenario), that is, a method or tool to identify activities that are needed urgently and feasible for Integrated Regional Development (PWT) especially for a Regional Tourism program. The mechanism process of this method is through a systematic participatory among actors (local government) and related stakeholders. This method is taken as this method is appropriate to determine strategic planning pattern, collective planning, awareness building and for networks strengthening. Samples are selected by proportionally stratified random sampling techniques, where sampling of members of the population is carried out randomly without regard to strata in the population. Informants in this study include: Sarolangun district government officials, and the community around tourist destinations. Location The research was carried out in Sarolangun Regency, Jambi Province with a focus of research in Sarolangun District and Limun District. This research was conducted on February 1 - March 12018.

\section{Findings And Discussion}

\section{Implementation of Policies on the Effectiveness of Developing Tourism Potential}

The results of the validity test of all indicators stated valid, because the value of $\mathrm{r}$ count> $\mathrm{r}$ table. Statements with the highest validity values are: the fourth statement, namely the dependency indicator (0.634), the eighth statement, namely the historical indicator (0.587), and the third statement, the historical time indicator (0.556). This means that these indicators dominantly influence the Effectiveness of Tourism Potential Development (Y). The statement with the lowest validity value is: the sixth statement, namely the competitiveness indicator and the first statement, namely the problem limitation indicator with a validity value of 0.161 . This means special attention is needed on competitiveness indicators and problem constraints. Likewise with the Reliability test, all indicators expressed as Reliable because of Alpha Cronbach $(\alpha)>$ r table $(0.650>0.1654)$. 
International Journal of Economics, Business and Accounting Research (IJEBAR)

Peer Reviewed - International Journal

Vol-3, Issue-4, 2019 (IJEBAR)

E-ISSN: 2614-1280 P-ISSN 2622-4771

http://jurnal.stie-aas.ac.id/index.php/IJEBAR

Table 1. Linearity Test Results of $X_{1}$

\begin{tabular}{|c|c|c|c|c|c|c|}
\hline \multicolumn{7}{|c|}{ ANOVA $^{\mathbf{a}}$} \\
\hline Model & & Sum of Squares & df & Mean Square & $\mathrm{F}$ & Sig. \\
\hline \multirow[t]{3}{*}{1} & Regression & 1124,953 & 1 & 1124,953 & 103,438 & $0,000^{\mathrm{b}}$ \\
\hline & Residual & 1065,807 & 98 & 10,876 & & \\
\hline & Total & 2190,760 & 99 & & & \\
\hline \multicolumn{7}{|c|}{ a. Dependent Variable: Effectiveness } \\
\hline b. Pred & ors: (Constan & licy Implementati & & & & \\
\hline
\end{tabular}

Based on Table 1, the linearity test results on the distribution obtained F 103,438 with Sig 0,000 , then the relationship of variables in this study is linear.

Table 2. Hypothesis Test Results of $\mathrm{X}_{1}$

\begin{tabular}{|l|l|l|l|l|}
\hline \multicolumn{4}{|c|}{ Model Summary } \\
\hline Model & R & R Square & Adjusted R Square & $\begin{array}{l}\text { Std. Error of the } \\
\text { Estimate }\end{array}$ \\
\hline 1 & $0,717^{\text {a }}$ & 0,513 & 0,509 & 3,298 \\
\hline a. Predictors: (Constant), Policy Implementation & \\
\hline b. Dependent Variable: Effectiveness \\
Source: Output SPSS 25 (data processing, 2019)
\end{tabular}

From the results of calculations in Table 2 of the Policy Implementation variable $\left(\mathrm{X}_{1}\right)$ summary model, the $\mathrm{R}$ Square value $\left(\mathrm{R}^{2}\right)$ is 0.513 or $51.3 \%$. For this reason, it was concluded that Policy Implementation had a $51.3 \%$ effect on the Effectiveness of Tourism Potential Development. While the rest $(48.7 \%)$, is influenced by other variables not examined in this study.

Tabel 3. Variable Coefficient of $X_{1}$

\begin{tabular}{|c|c|c|c|c|c|c|c|c|}
\hline \multicolumn{9}{|c|}{ Coefficients $^{\mathbf{a}}$} \\
\hline \multirow{2}{*}{\multicolumn{2}{|c|}{ Model }} & \multicolumn{2}{|c|}{$\begin{array}{l}\text { Unstandardized } \\
\text { Coefficients }\end{array}$} & \multirow{2}{*}{$\begin{array}{c}\text { Standardized } \\
\text { Coefficients } \\
\text { Beta }\end{array}$} & \multirow[t]{2}{*}{$\mathrm{t}$} & \multirow[t]{2}{*}{ Sig. } & \multicolumn{2}{|c|}{$\begin{array}{l}\text { Collinearity } \\
\text { Statistics }\end{array}$} \\
\hline & & B & Std. Error & & & & Tolerance & VIF \\
\hline \multirow[t]{2}{*}{1} & (Constant) & 0,176 & 3,947 & & 0,045 & 0,964 & & \\
\hline & Policy Implementation & 0,995 & 0,098 & 0,717 & 10,170 & 0,000 & 1,000 & 1,000 \\
\hline
\end{tabular}

Based on Table 3, the Coefficient of Variable $\mathrm{X}_{1}$ from the SPSS calculation results is $\mathrm{P}_{\mathrm{X} 1}$ $=0.995$, with the value of $t$ count $=10.170$ at the value of $t$ table $=1.29043$. This value expresses $\mathrm{t}$ count $>\mathrm{t}$ table, meaning that the path coefficient is significant. From these findings, it can be interpreted that Policy Implementation $\left(\mathrm{X}_{1}\right)$ has an effect on the Effectiveness of Tourism Potential Development in Sarolangun Regency. Whereas Coefficients ${ }^{\mathrm{a}} \mathrm{X}_{1}$ column B at constant (a) 0.176 and $\mathrm{X} 1$ value (b) 0.995 , so the regression equation is as follows:

$$
\begin{aligned}
& \hat{Y}=\mathbf{a}+\mathbf{b} \mathbf{X}_{\mathbf{1}} \\
& \hat{\mathrm{Y}}=0,176+0,995 \mathbf{X}_{\mathbf{1}}
\end{aligned}
$$

The statistical results show that the Policy Implementation contributes significantly to the Effectiveness of Tourism Potential Development. That is, the better the Implementation of Policies, the Increasing the Effectiveness of Tourism Potential Development with a Beta Coefficient value of 0.995 . 


\section{Investment in the Effectiveness of Developing Tourism Potential}

The results of the validity test of all indicators are declared valid because of the valuer count> $r$ table. The statement with the highest validity value is the eighth statement, the stock price indicator (0.922), the fourth statement, the scientific study indicator $(0.366)$, and the tenth statement, the guarantee indicator (0.308). This means that these indicators dominantly influence the Effectiveness of Tourism Potential Development (Y). The lowest validity value is the seventh statement, a high demand indicator with a validity value of 0.159 . This means special attention is needed on the high demand indicator. Likewise with the Reliability test, all indicators are declared Realiabel because of alpha cronbach $(\alpha)>r$ table $(0.341>0.1654)$.

Table 4. Linearity Test Results of $\mathbf{X}_{2}$

\begin{tabular}{|c|c|c|c|c|c|c|}
\hline \multicolumn{7}{|c|}{ ANOVA $^{\mathbf{a}}$} \\
\hline \multicolumn{2}{|l|}{ Model } & Sum of Squares & df & Mean Square & $\mathrm{F}$ & Sig. \\
\hline \multirow[t]{3}{*}{1} & Regression & 338,475 & 1 & 338,475 & 17,908 & $0,000^{\mathrm{b}}$ \\
\hline & Residual & 1852,285 & 98 & 18,901 & & \\
\hline & Total & 2190,760 & 99 & & & \\
\hline \multicolumn{7}{|c|}{ a. Dependent Variable: Effectiveness } \\
\hline \multicolumn{7}{|c|}{ b. Predictors: (Constant), Investment } \\
\hline
\end{tabular}

Source: Output SPSS 25 (data processing, 2019)

Based on Table 4, the linearity test results on the distribution obtained F 17.908 with Sig 0.000 , then the relationship of variables in this study is linear.

Table 5. Hypothesis Test Results $X_{2}$

\begin{tabular}{|c|c|c|l|c|}
\hline \multicolumn{5}{|c|}{ Model Summary } \\
\hline Model & $\mathrm{R}$ & $\mathrm{R}$ Square & Adjusted R Square & $\begin{array}{c}\text { Std. Error of the } \\
\text { Estimate }\end{array}$ \\
\hline 1 & $0,393^{\mathrm{a}}$ & 0,155 & 0,146 & 4,348 \\
\hline a. Predictors: (Constant), Investment \\
Source: Output SPSS 25 (data processing, 2019)
\end{tabular}

From the results of the calculation of Table 5 the investment variable summary model $\left(\mathrm{X}_{2}\right)$ to determine the value of $\mathrm{R}$ Square $\left(\mathrm{R}^{2}\right)$ of 0.155 or $15.5 \%$. For this reason, it can be concluded that the Investment variable influences $15.5 \%$ of the Effectiveness of Tourism Potential Development, and the rest $(84.5 \%)$ is influenced by other variables not examined in this study.

Table 6. Variable Coefficient of $\mathrm{X}_{2}$

\begin{tabular}{|c|c|c|c|c|c|c|c|c|}
\hline \multicolumn{9}{|c|}{ Coefficients $^{\mathrm{a}}$} \\
\hline \multirow{2}{*}{\multicolumn{2}{|c|}{ Model }} & \multicolumn{2}{|c|}{$\begin{array}{l}\text { Unstandardized } \\
\text { Coefficients }\end{array}$} & \multirow{2}{*}{$\begin{array}{c}\begin{array}{c}\text { Standardized } \\
\text { Coefficients }\end{array} \\
\text { Beta }\end{array}$} & \multirow{2}{*}{$\mathrm{t}$} & \multirow{2}{*}{ Sig. } & \multicolumn{2}{|c|}{ Collinearity Statistics } \\
\hline & & B & Std. Error & & & & Tolerance & VIF \\
\hline \multirow[t]{2}{*}{1} & (Constant) & 2,693 & 8,869 & & 0,304 & 0,762 & & \\
\hline & Investment & 0,948 & 0,224 & 0,393 & 4,232 & 0,000 & 1,000 & 1,000 \\
\hline
\end{tabular}

Source: Output SPSS 25 (data processing, 2019)

Based on Table 6, the Coefficient of Variable $\mathrm{X}_{2}$ from the SPSS calculation results is $\mathrm{P}_{\mathrm{X} 2}=0.948$ with $t$-count $=4.232$ at table value $=1.29043$. This value expresses $t$-count $>t$-table, meaning that 
the path coefficient is significant, this finding can be interpreted that Investment $\left(\mathrm{X}_{2}\right)$ affects the Effectiveness of Tourism Potential Development in Sarolangun Regency. Whereas Coefficients ${ }^{\mathrm{a}}$ $\mathrm{X}_{2}$ column $\mathrm{B}$ on constant (a) 2.693 and $\mathrm{X} 2$ value (b) 0.948 , so the regression equation is as follows:

$\hat{Y}=a+b X_{2}$

$\hat{Y}=2,693+0,948 \mathbf{X}_{2}$

The statistical results show that investment contributes significantly to the Effectiveness of Tourism Potential Development. That is, the better the investment, the more effective the Development of Tourism Potential with a Beta Coefficient of 0.948 .

\section{Business Executors Against the Effectiveness of Developing Tourism Potential}

The results of the validity test of all indicators are declared valid because of the value $r$ count $>\mathrm{r}$ table. The statement with the highest validity value is the eighth that is the social group indicator (0.627), the fourth statement, the local community indicator (0.611), and the third statement, the customer or consumer indicator (0.595). This means that these indicators dominantly influence the Effectiveness of Tourism Potential Development (Y). The lowest validity value is the sixth statement, a government indicator with a validity value of $(0.148)$. This means special attention is needed on government indicators. Likewise with the Reliability test, all indicators expressed as Reliable because of alpha cronbach $(\alpha)>r$ table $(0.659>0.1654)$.

Table 7. Linearity Test Results of $\mathrm{X}_{3}$

\begin{tabular}{|c|c|c|c|c|c|c|}
\hline \multicolumn{7}{|c|}{$\mathrm{ANOVA}^{\mathrm{a}}$} \\
\hline \multirow{4}{*}{\begin{tabular}{|l}
$1010 \mathrm{del}$ \\
1
\end{tabular}} & & Sum of Squares & df & Mean Square & $\mathrm{F}$ & Sig. \\
\hline & Regression & 1151,924 & 1 & 1151,924 & 108,668 & $0,000^{\mathrm{b}}$ \\
\hline & Residual & 1038,836 & 98 & 10,600 & & \\
\hline & Total & 2190,760 & 99 & & & \\
\hline \multicolumn{7}{|c|}{ a. Dependent Variable: Effectiveness } \\
\hline b. Predi & ors: (Constan & siness Executor & & & & \\
\hline
\end{tabular}

Based on Table 7, the linearity test results on the distribution obtained F 108,668 with Sig 0,000, then the relationship of variables in this study is linear.

Table 8. Hypothesis Test Results of $\mathrm{X}_{3}$

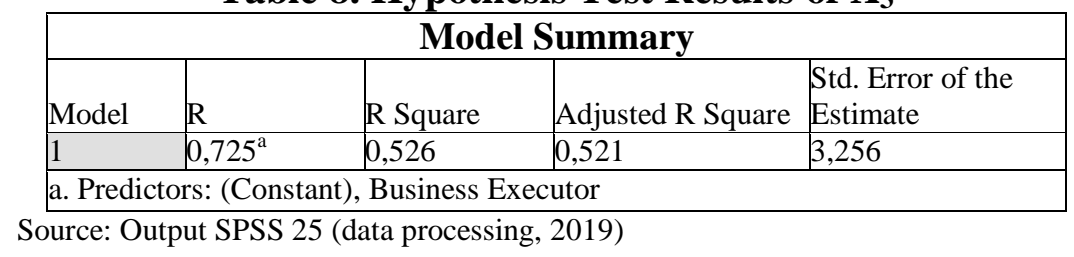

From the results of the calculation of Table 8, the Business Model variable summary (X3) for the $\mathrm{R}$ Square Value determination (R2) is 0.526 or $52.6 \%$. For this reason, it can be concluded that Business Executors influence 52.6\% of the Effectiveness of Tourism Potential Development, and the rest $(47.4 \%)$ is influenced by other variables not examined in this study. 
International Journal of Economics, Business and Accounting Research (IJEBAR)

Peer Reviewed - International Journal

Vol-3, Issue-4, 2019 (IJEBAR)

E-ISSN: 2614-1280 P-ISSN 2622-4771

http://jurnal.stie-aas.ac.id/index.php/IJEBAR

Table 9. Variable Coefficient of $\mathbf{X}_{3}$

\begin{tabular}{|c|c|c|c|c|c|c|c|}
\hline \multicolumn{8}{|c|}{ Coefficients $^{\mathrm{a}}$} \\
\hline \multirow[t]{2}{*}{ Model } & \multicolumn{2}{|c|}{$\begin{array}{l}\text { Unstandardized } \\
\text { Coefficients }\end{array}$} & \multirow{2}{*}{$\begin{array}{c}\text { Standardized } \\
\text { Coefficients }\end{array}$} & \multirow[t]{2}{*}{$\mathrm{t}$} & \multirow[t]{2}{*}{ Sig. } & \multicolumn{2}{|c|}{$\begin{array}{l}\text { Collinearity } \\
\text { Statistics }\end{array}$} \\
\hline & $\mathrm{B}$ & Std. Error & & & & Tolerance & VIF \\
\hline (Constant) & 0,559 & 3,815 & & 0,146 & 0,884 & & \\
\hline Pelaku Usaha & 0,979 & 0,094 & 0,725 & 10,424 & 0,000 & 1,000 & 1,000 \\
\hline
\end{tabular}

Source: Output SPSS 25 (data processing, 2019)

Based on Table 9, the coefficient of Variable $\mathrm{X}_{3}$ from the SPSS calculation results is $\mathrm{P}_{\mathrm{X} 3}=0.979$ with $\mathrm{t}$ count $=10.424$ and $\mathrm{t}$ table $=1.29043$. This value expresses $\mathrm{t}$-count $>\mathrm{t}$-table, that's meaning the path coefficient is significant, this finding can be interpreted that Business Executors $\left(\mathrm{X}_{3}\right)$ affect the Effectiveness of Tourism Potential Development in Sarolangun Regency. Whereas Coefficientsa $\mathrm{X}_{3}$ column $\mathrm{B}$ on constant (a) 0.559 and $\mathrm{X} 3$ value (b) 0.979 , so the regression equation is as follows:

$$
\begin{aligned}
\hat{Y} & =\mathbf{a}+\mathbf{b} \mathbf{X}_{\mathbf{3}} \\
\hat{\mathrm{Y}} & =0,559+0,979 \mathbf{X}_{\mathbf{3}}
\end{aligned}
$$

The statistical results show that business executors make a real contribution to the Effectiveness of Tourism Potential Development. That is, the better the business executor, the more effective the Development of Tourism Potential with a Beta Coefficient value of 0.979.

\section{Implementation of Policies, Investment, and Business Executors on the Effectiveness of Developing Tourism Potential}

Table 10. Normality Test Results $X_{1}, X_{2}, X_{3}, X_{4}$

\begin{tabular}{|l|l|c|c|c|c|}
\hline \multicolumn{6}{|c|}{ One-Sample Kolmogorov-Smirnov Test } \\
\hline \multicolumn{2}{|c|}{} & \multicolumn{4}{c|}{ Unstandardized Residual } \\
\hline \multirow{2}{*}{$\mathbf{N}$} & $\mathrm{X}_{1}$ & $\mathrm{X}_{2}$ & $\mathrm{X}_{3}$ & $\mathrm{X}_{1}, \mathrm{X}_{2}, \mathrm{X}_{3}$ \\
\hline \multirow{2}{*}{ Normal Parameters } & & 100 & 100 & 100 & 100 \\
\hline \multirow{2}{*}{ Most Extreme Differences } & Mean & 0,0000000 & 0,0000000 & 0,0000000 & 0,0000000 \\
\cline { 2 - 6 } & Std. Deviation & 3,28111687 & 4,32550006 & 3,23933565 & 3,23177673 \\
\cline { 2 - 6 } & Absolute & 0,089 & 0,103 & 0,072 & 0,065 \\
\cline { 2 - 6 } & Positive & 0,062 & 0,062 & 0,070 & 0,042 \\
\cline { 2 - 6 } & Negative & $-0,089$ & $-0,103$ & $-0,072$ & $-0,065$ \\
\hline Test Statistic & 0,089 & 0,103 & 0,072 & 0,065 \\
\hline Asymp. Sig. (2-tailed) & $0,048^{\mathrm{c}}$ & $0,011^{\mathrm{c}}$ & $0,200^{\mathrm{c}, \mathrm{d}}$ & $0,200^{\mathrm{c}, \mathrm{d}}$ \\
\hline
\end{tabular}

Source: Output SPSS 25 (data processing, 2019)

a. Test distribution is Normal.

b. Calculated from data.

c. Lilliefors Significance Correction.

$\mathrm{d}$. This is a lower bound of the true significance.

Based on Table 10, it can be seen that the significance value of $X_{1}$ to $Y(0.048<0.05), X_{2}$ against $\mathrm{Y}(0.011<0.05), \mathrm{X}_{3}$ against $\mathrm{Y}(0.200>0.05)$ and $\mathrm{X}_{1}, \mathrm{X}_{2}, \mathrm{X}_{3}$ are tested simultaneously against $Y(0,200>0.05)$, so it is concluded that the data tested $X_{1}$ against $Y$ and the test data $X_{2}$ against $\mathrm{Y}$ are not normally distributed, the data tested on $\mathrm{X}_{3}$ against $\mathrm{Y}$ and $\mathrm{X}_{1}, \mathrm{X}_{2}, \mathrm{X}_{3}$ is tested simultaneously on normal distribution Y. 
International Journal of Economics, Business and Accounting Research (IJEBAR)

Peer Reviewed - International Journal

Vol-3, Issue-4, 2019 (IJEBAR)

E-ISSN: 2614-1280 P-ISSN 2622-4771

http://jurnal.stie-aas.ac.id/index.php/IJEBAR

Table 11. Hypothesis Test Results $X_{1}, X_{2}, X_{3}, X_{4}$ Against $Y$

\begin{tabular}{|l|l|l|l|l|}
\hline \multicolumn{5}{|c|}{ Model Summary } \\
\hline Model & $\mathrm{R}$ & R Square & Adjusted R Square & $\begin{array}{l}\text { Std. Error of the } \\
\text { Estimate }\end{array}$ \\
\hline 1 & $0,727^{\mathrm{a}}$ & 0,528 & 0,513 & 3,282 \\
\hline a. Predictors: (Constant), Business Executor, Investment, Policy Implementation \\
\hline
\end{tabular}

From the results of the calculation of Table 11, the summary model of Policy Implementation $\left(\mathrm{X}_{1}\right)$, Investment $\left(\mathrm{X}_{2}\right)$, and Business Executor $\left(\mathrm{X}_{3}\right)$ variables together for the determination test gets an $\mathrm{R}$ Square Value of 0.528 or $52.8 \%$. For this reason, it can be concluded that the implementation of Policy $\left(\mathrm{X}_{1}\right)$, Investment $\left(\mathrm{X}_{2}\right)$, and Business Executors $\left(\mathrm{X}_{3}\right)$ together influence $52.8 \%$ of the Effectiveness of Tourism Potential Development, and the rest (47.2\%) is influenced by other variables not examined in this study.

Table 12. Variable Coefficient of $X_{1}, X_{2}, X_{3}, X_{4}$

\begin{tabular}{|c|c|c|c|c|c|c|c|c|}
\hline \multicolumn{9}{|c|}{ Coefficients $^{\mathbf{a}}$} \\
\hline \multirow{2}{*}{\multicolumn{2}{|c|}{ Model }} & \multicolumn{2}{|c|}{$\begin{array}{l}\text { Unstandardized } \\
\text { Coefficients }\end{array}$} & \multirow{2}{*}{\begin{tabular}{|l|}
$\begin{array}{l}\text { Standardized } \\
\text { Coefficients }\end{array}$ \\
Beta
\end{tabular}} & \multirow[t]{2}{*}{$\mathrm{t}$} & \multirow{2}{*}{ Sig. } & \multicolumn{2}{|c|}{ Collinearity Statistics } \\
\hline & & $\mathrm{B}$ & Std. Error & & & & Tolerance & VIF \\
\hline \multirow[t]{4}{*}{1} & (Constant) & 1,454 & 6,722 & & 0,216 & 0,829 & & \\
\hline & Business Executor & 0,711 & 0,427 & 0,527 & 1,667 & 0,099 & 0,049 & 20,343 \\
\hline & Investment & $-0,053$ & 0,209 & $-0,022$ & $-0,256$ & 0,799 & 0,655 & 1,527 \\
\hline & Policy Implementation & 0,299 & 0,451 & 0,216 & 0,664 & 0,508 & 0,047 & 21,466 \\
\hline
\end{tabular}

Based on Table 12, the Variable Coefficients X1, X2, X3, together from the SPSS calculation results are Px4 $=1.454$, with a $t$ count value of 0.216 on the table value $=1.29043$. This value expresses $t$ count $>t$ table, meaning that the path coefficient is significant, this finding can be interpreted that Policy Implementation $\left(\mathrm{X}_{1}\right)$, Investment $\left(\mathrm{X}_{2}\right)$, and Business Executor $\left(\mathrm{X}_{3}\right)$ together have a significant effect on the Effectiveness of Tourism Potential Development in the Regency Sarolangun. So Coefficientsa X4 column B in constant (a) (a) 1.454 while the value of $\mathrm{X} 1$ (b) $0,299, \mathrm{X} 2$ (b) $-0,053$, and X3 (b) 0,711, so the regression equation is as follows:

$$
\begin{aligned}
& \hat{Y}=\mathbf{a}+\mathbf{b} \mathbf{X}_{\mathbf{1}}+\mathbf{b} \mathbf{X}_{\mathbf{2}}+\mathbf{b} \mathbf{X}_{\mathbf{3}} \\
& \hat{Y}=1,454+0,299 \mathbf{X}_{\mathbf{1}}+(-0,053) \mathbf{X}_{\mathbf{2}}+0,711 \mathbf{X}_{\mathbf{3}} \\
& \hat{Y}=1,454+0,299 \mathbf{X}_{\mathbf{1}}-0,053 \mathbf{X}_{\mathbf{2}}+0,711 \mathbf{X}_{\mathbf{3}}
\end{aligned}
$$

The statistical results show that the Implementation of Policies, Investment, and Business Executors together have a significant effect on the Effectiveness of the Development of Tourism Potential in Sarolangun Regency. That is, the better the Implementation of Policy, Investment, and Business Executors together, the better the Effectiveness of Tourism Potential Development.

\section{Findings and Practical Implications of Research Results}

Researchers held a workshop "Identification and Mapping of the Sarolangun District Tourism Area". As for the participants who attended and participated in the identification workshop, namely: Related Service Staff, Representatives of the Indonesian National Police / 
TNI, Representatives of the Sub-District Head of Sarolangun District, Lecturers \& Students / Higher Education Institutions in Sarolangun, High School / Equivalent Representatives in Sarolangun District and Media Representatives. In this case, carried out in the form of data collection withparticipatory methods.

The researcher uses the S-PWT (Integrated Regional Development Scenario) by LEKAD, which is a method as well as a tool to identify the needs of decent and urgent Integrated Development (PWT) activities to be developed as well as a regional program, which in this case is a Regional Tourism program. This process is through a systematic participatory mechanism between the executors (local government) and relevant stakeholders. This method is taken as a method that is appropriate with the utilization of strategic planning patterns, collective planning, activation of shared awareness (awareness building) and strengthening of networks (networking), and in accordance with this research.

The results of identifying the strategic issues of tourism in the Sarolangun Regency obtained were the acquisition of 21 strategic issues so that $20 \%$ of the most important and most problematic strategic issues were taken, the result of the 21 issues there were 4 strategic issues including: Road Access of 11/10, Local Wisdom 5/5, Economy 4/5 and environment 4/5. The four strategic issues state that tourism in Sarolangun Regency requires an independent Institutional dimension that cares in dealing with tourism and professional human resources in their fields.

Furthermore, mapping the Sarolangun Regency's tourism strategic area is the mapping of the Sarolangun Regency's tourism area, a ranking of potential destinations that can be developed are: (1) Destination $\mathrm{C}$ with a total weight of 4.75 that is the Cikminah Ancol Edge located in Sarolangun District. (2) Destination E, with a total weight of 3.75 , is the Basamo Page of Sriwijaya field, located in Sarolangun District. (3) Destination A has a total weight of 3.25, namely Air Hitam Tourism, which is located in Air Hitam District. (4) Destinations B and D have a total weight of 2.75, namely Batang Asai Tourism, which is located in Batang Asai District; and Lake Biaro which is located in the village of Lidung, Sarolangun District. (5) Destination $\mathrm{H}$ has a total weight of 2.5, namely Lake Pauh which is located in Pauh District. (6) Destination F has a total weight of 2.25, namely Goa Colau Petak which is located in Limun District. And (7) Destination G has a total weight of 2: Batu Empang Waterfall which is located in Batang Asai District.

Thus, potential districts for tourism development in Sarolangun Regency are Sarolangun District, Limun District, Pauh District, Air Hitam District and Batang Asai District. In accordance with the identification and mapping of the tourism area, a Rapid Monitoring and Evaluation was conducted at the end of the workshop. 


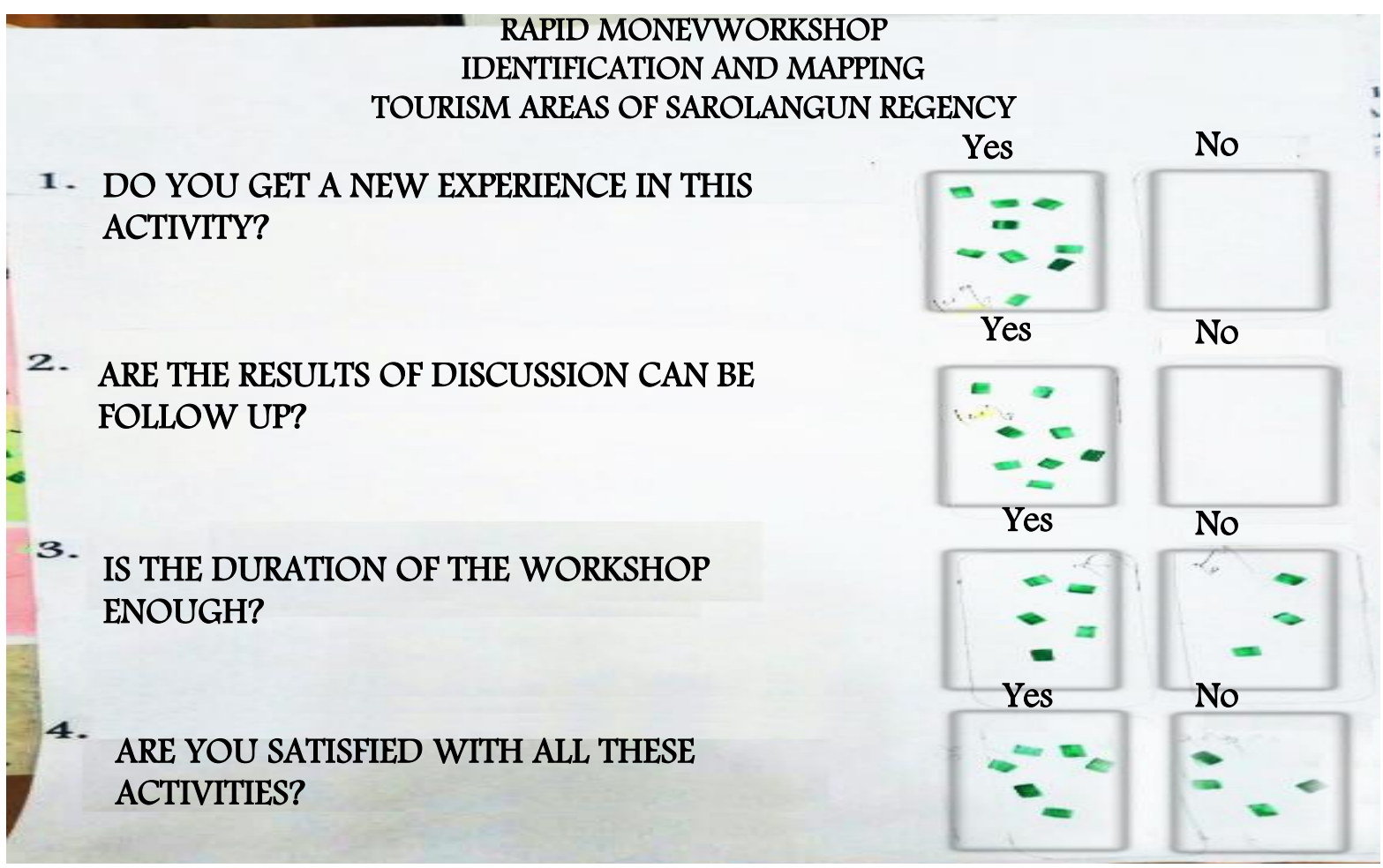

Figure 1.

Rapid Monev

The results of rapid monev and evaluation are as follows:

1) $100 \%$ Participants gain new experience in this activity.

2) $100 \%$ of participants stated that the results of the discussion could be followed up.

3) $75 \%$ of participants said that the duration of the workshop was sufficient.

4) $60 \%$ of participants expressed satisfaction with the overall activity.

After the Workshop, the researchers continued their field research to NapalMelintang Village, Limun District, Sarolangun Regency. Some things that are very concerning include: (1) Road access from the capital of the sub-district to NapalMelintang Village, Bukit Bulan which is damaged. (2) When being located, building bridges into caves is less attractive because they do not use rocks as stairs. (3) Cleanliness around and inside the cave is also poorly maintained. Likewise with Temulun Hill, the access is quite far from the people's housing, the location is not maintained and the DAM built at the tourist location is not functioning optimally. So it takes a special manager in each tourist destination.

The Promotion of Tourism in Sarolangun Regency has not been maximized and technology has not been effectively utilized as a promotional media, especially for tourism objects in Air Hitam District, Limun District, and Sarolangun District. moreover, there are no investors interested in investing in the development of artificial tourism and nature tourism in this area. Existing 
tourism is not very well known by people outside the Sarolangun Regency and there is no deep impression for tourists, which has an impact on the number of visitors.

\section{Conclusion andSuggestation}

\section{Conclusion}

The following are some conclusions from this research:

1) There is an Effect of Policy Implementation on the Effectiveness of Tourism Potential Development of 51.3\%. This concludes that the Regional Tourism Policy Implementation also regulates tourism business executors. Thus, it is expected that the implementation of tourism policy in Sarolangun Regency will be more developed and innovative, and attract investors to be able to invest in the regional tourism sector.

2) There is an Investment Impact on the Effectiveness of the Development of Tourism Potential of $15.5 \%$. This concludes the Investment for regional investors in Sarolangun Regency, in order to be able to help the Regional Government prosper the community through tourism investment in the form of supporting facilities and infrastructure in Sarolangun Regency tourism sites. And the Government must try to invite the public to protect assets, help heed, promote and monitor, the development of tourism investment in the region.

3) There is an Effect of Business Executors on the Effectiveness of Tourism Potential Development of 52.6\%. This concludes that Business Executors can work together with business executors / stakeholders and open a conducive business climate in the Tourism sector in each tourist destination.

4) There is an Effect of Policy Implementation, Investment and Business Executors simultaneously on the Effectiveness of the Development of Tourism Potential 52.8\%. This concludes the importance of Policy Implementation, Investment and Business Executors and Effectiveness in the Development of Tourism Potential in developing the potential of the Sarolangun Regency.

\section{Suggestion}

Suggestions from this research:

1) Dimension Identification of problems and recommendation dimensions supported by the Monitoring dimension requires special attention by the Regional Government, through efforts: (a) identification and mapping of development needs for each tourist destination in Sarolangun District, (b) follow-up recommendations from the workshop results "Identification and Mapping Sarolangun District Tourism Area ", (c) administrative control in each District related data: tourists, managers, tourism programs, lodging and restaurants around tourist sites and destination documentation on a regular basis, (d) Local Governments need to restructure government organizations regions (re-establishing the Department of Tourism) and, (e) drawing up a Regional Regulation on the governance of the tourism destination areas of Sarolangun and RIPPARDA Regencies.

2) Dimensions of Profit Level require special attention by the Regional Government, through: (a) efforts to improve the business climate based on the built home industry in particular 
opening up the business climate of the tourism sector, (b) allocating funds for domestic investment in the tourism sector, and (c) increasing security invest for investors.

3) The Secondary Stakeholder Dimension requires special attention through efforts: (a) training for tourism assistants, especially local communities, (b) forming independent institutions / organizations to manage tourism in each destination location such as tourism awareness groups and the Regional Tourism Management Forum ( FTKPD).

4) The dimensions of the Tourism Organization and the Accessibility dimension require special attention through efforts: (a) restructuring of government organizations by re-establishing the Tourism Office, (b) forming regional tourism management organizations or bodies such as: regional tourism governance forums (FTKP), (c) to improve road access from and to tourist sites and (d) prepare special public transportation to tourist sites such as access from the capital city of Sarolangun to tourist sites in Limun, BatangAsai and Air Hitam districts.

\section{References}

Solichin, A. W. (2008). Analisis Kebijakan: Dari Formulasi ke Implementasi Kebijakan Negara. Jakarta: Bumi Aksara.

Blackman, R.(2003). Project Cycle Management, ROOTS Resources5, Tearfund, London, UK.

De Carvalho, D. D. A., do Carmo, H. P. F. V., Cruz, C., \& Samson, G. (2008). Outro Mundo é Posivel Através Turismo Etico.

Deliarnov. (1995). Pengantar Ekonomi Makro. Jakarta: UI-Press.

Hutan, D. J. P. (2001). Pedoman Pengembangan Pariwisata Alam di Taman Nasional-Untuk Pengelola dan Para Pihak.

Dunn, W. N. (1999). Pengantar Analisa Kebijakan Publik, ctk. 2.

Inovasi, S. H. S. (2003). Partisipasi dan Good Governance. Bandung: Yayasan Obor Indonesia.

Keban, Y. T. (2008). Enam Dimensi Strategis Administrasi Publik: Konsep, Teori, dan Isu, Edisi Kedua. Cetakan Pertama. Yogyakarta: Penerbit Gaya Media.

Rahim, F. (2012). Pedoman Pokdarwis. Jakarta: Direktur Jenderal Pengembangan Destinasi Pariwisata Kementrian Pariwisata dan Ekonomi Kreatif.

Bodger, D. (1998). Leisure, learning, and travel. Journal of Physical Education, Recreation \& Dance, 69(4), 28-31.

Sugiyono, P. Dr. 2010. Metode Penelitian Kuantitatif, Kualitatif, dan R\&D. Bandung: CV Alfabeta.

Sukirno, S. (2001). PengantarMakro Ekonomi: Edisi II. Jakarta: Grafindo Persada. 
International Journal of Economics, Business and Accounting Research (IJEBAR)

Peer Reviewed - International Journal

Vol-3, Issue-4, 2019 (IJEBAR)

E-ISSN: 2614-1280 P-ISSN 2622-4771

http://jurnal.stie-aas.ac.id/index.php/IJEBAR

Sunaryo, B. (2013). Kebijakan pembangunan destinasi pariwisata: konsep dan aplikasinya di Indonesia (No. 1). Penerbit Gava Media Kebijakan Pembangunan Destinasi Pariwisata: Konsep dan Aplikasinya di Indonesia. 